Viewpoints and Letters to the Editor are published in Hort- comments on matters of concern to horticulturists. These are Science to provide members of the American Society for Hor- not statements of official Society policy nor do they necessarticultural Science an opportunity to share their experiences and ily reflect the views of a majority of the Society's members.

\title{
Extension and Applied Research in the European Community and the United States
}

\author{
E.B. Poling, ${ }^{1}$ J.G. Richardson ${ }^{2}$, and G.A. Benson ${ }^{3}$ \\ North Carolina Agricultural Extension Service, North Carolina State University, Raleigh, NC 27695-7609
}

European agriculture has undergone dramatic changes during the last 25 years and the European Community is a major economic and political force in the world food and agriculture scene. The European Community has grown from six member countries in 1965 to 12 today, and has changed from being a major net food importer to being self-sufficient in most major commodities and a major exporter of several others.

The restructuring and modernization of European agriculture has been brought about by the extensive use of farm programs and the adoption of new technology. In fact, an efficient agricultural sector had developed that now produces too much, according to $\mathrm{H}$. Verstijlen, Assistant to the Deputy Director General for Markets of the European Commission (Table 1).

Despite, or perhaps because of, an abundance of relatively cheap food in Europe today, the public takes for granted the contributions of a modernized agricultural sector. In fact, the wave of ecology and health consciousness in northern Europe (unlike anything we have yet experienced in the United States) has cast a very negative light on modem agriculture's achievements. The "Green" movement and animal welfare activists are causing ever greater regulations to be placed on agricultural producers. According to N. Roling (1989, unpublished), agricultural overproduction and pollution concerns outweigh in the public mind the positive contributions of agriculture, namely cheap food and very high export production.

Similarly, the director general of the agricultural advisory services in England and Wales has stated that the average voter has

Received for publication 22 Feb. 1990. Paper no. 206 of the Journal Series of the N.C. Agricultural Research Service, Raleigh, NC 27695-7643. We wish to gratefully acknowledge the financial support of Philip Morris USA for the North Carolina Agriculture in the World program, 1989-1990. The cost of publishing this paper was defrayed in part by the payment of page charges. Under postal regulations, this paper therefore must be hereby marked advertisement solely to indicate this fact.

'Associate Professor, Dept. of Horticultural Science.

${ }^{2}$ Associate Professor, Extension Specialist Educational Programs, North Carolina Agricultural Extension Service.

${ }^{3}$ Associate Professor, Dept. of Economics and Business. become disenchanted with farming because of the mounting cost of the disposal of surplus agricultural production, and that many of today's voters have little concern for the security offered by domestic food supplies (Bell and Bunney, 1985):

. . their eyes set on higher things like the beauty of the countryside which they see as being threatened by modem systems of agricultural production, or on food which is produced by what they regard as "natural" as opposed to "factory farming" methods.

Guilt by association is a public relations problem for extension workers in the agricultural advisory extension systems of the countries of northern Europe.

A contrast between the European Community and the United States is the move in several European countries, including England, the Netherlands, and the Federal Republic of Germany, toward funding extension through user fees. In the Netherlands, for example, the target is for user fees to provide $50 \%$ of the extension service budget. Predictably, this requirement means that the clients of the agricultural advisory services must be viewed as "customers" rather than "adult learners." Furthermore, those clients and their problems now must be evaluated by extension workers in terms of the potential fees that might be collected, which affects program priorities and places extension workers in competition with private agricultural consultants.

An alarmed Nitsch (1989) relates in his address on Present Trends in the European Agricultural Advisory Services:

. . your value as an advisory worker is now assessed solely on the basis of the income you generate for the organization.

The appropriateness of user fees for extension programs hinges on the issue of "education" vs. "service." Service implies a product that meets an immediate need of the client, and the client alone receives the full benefit. By definition, education is broader, less specific, and seeks to make the learner aware of problems and opportunities that otherwise might be overlooked. Furthermore, education may yield broader benefits than those that accrue to the learner alone. For example, increased productivity in agriculture contributes to the growth of the total economy and reduces food costs to consumers. This is one justification for public funding of education, including extension education programs.

Extension programs, however, typically include both service and education, and so the counter-argument can be made that the fee-for-service approach has forced European extension workers to pay closer attention to the information and products most needed by producers. In this situation, the client is more likely to receive the service requested, rather than the service being offered by the so-called change agent (Gerber, 1989).

In other words, the willingness to pay for a particular service is the most effective means of judging its value. There are many instances when U.S. extension workers provide services to individual farm families that presumably result in economic benefits to

Table 1. Self-sufficiency in the European Economic Community'; selected agricultural commodities, 1985-86

\begin{tabular}{lc}
\hline Commodity & $\begin{array}{c}\text { Self-sufficiency } \\
(\%)\end{array}$ \\
\hline Total cereals & 114 \\
Wheat & 126 \\
Maize & 82 \\
Potatoes & 102 \\
Sugar & 129 \\
Fresh vegetables & $107^{\mathrm{y}}$ \\
Fresh fruit (excl. citrus) & $87^{\mathrm{y}}$ \\
Wine & 105 \\
Dairy products & \\
Butter & $133^{\mathrm{x}}$ \\
Cheese & $106^{\mathrm{x}}$ \\
Nonfat Dry Milk & $118^{\mathrm{x}}$ \\
Total meat & $102^{\mathrm{w}}$ \\
Beef & $108^{\mathrm{w}}$ \\
Pork & $102^{\mathrm{w}}$ \\
Poultry & $107^{\mathrm{w}}$ \\
Vegetable oils & $49^{\mathrm{w}}$ \\
\hline
\end{tabular}

${ }^{2}$ Belgium, Denmark, France, Federal Republic of Germany, Greece, Ireland, Italy, Luxembourg, Netherlands, Portugal, Spain, United Kingdom. y1985 data.

x1984 data.

w1986 data.

Source: The Agricultural Situation in the Community; 1988 Report, Commission of the European Communities, Office for Official Publications of the European Communities, Luxembourg, 1989. 
those families alone and could therefore be used to argue in favor of charging fees, although it should be noted that, within limits, these activities are a necessary component of the overall extension program and yield benefits to the extension workers as well as the families concerned.

In general, it appears that the European advisory services do not share the philosophy, mission, and scope of the U.S. Cooperative Extension System, namely education and the dissemination of applied, researchbased knowledge to the rural population. For example, the U.S. Cooperative Extension System has been given a public mandate to work on a broad range of issues of public concern, as described in the national initiatives. These include the socioeconomic problems of environmental protection, sustainable agriculture, revitalizing the rural economy, building human capital, and improving nutrition, diet, and health, whereas the major emphasis in Europe has been placed on production agriculture and not the other components $(4-\mathrm{H}$, natural resources development, etc.) that are a part of the U.S. Cooperative Extension System (Funt, 1991).

The organization of the agricultural advisory services in the European Community varies, but, in general, they are the responsibility of the ministry of agriculture in the individual member countries. Two exceptions are the Federal Republic of Germany, where the advisory services have been the exclusive responsibility of the individual states since 1973, and Scotland, where these activities operate under the colleges of agriculture of three of the Scottish universities. Publicly funded agricultural research also is conducted at research stations under the control of the ministries of agriculture. However, the advisory service almost always is organized and located quite apart from the major research organizations and from the agricultural universities. Also, the research institutions tend to be quite specialized and organized around commodities. The land grant university concept is unique to the United States. European extension workers seem to appreciate and applaud the U.S. system where extension is integrated within the land grant university system and researchers and extension workers are readily accessible to each other.
There are, then, some marked differences in the structure, goals, and working environment between the U.S. and European extension services. The state extension services in the United States have a broad mission; they have the flexibility and autonomy to select programs that address the priorities of the state, they have ready access to research support and enjoy public and political support. In contrast, European extension services are expected to become at least partly self-sufficient by charging fees and must also respond to regulations and concerns from highly critical nonfarm sources. This has given rise to a different agenda and set of priorities, including more emphasis on longer range environmental, social, and ethical goals. In this regard, environmental and animal welfare regulations and concerns in Europe appear to be ahead of the United States. Research and extension programs have been forced to address such issues as the design of farm production systems to alleviate ground water contamination and livestock facilities that meet more stringent animal welfare guidelines than those in the United States. This requirement suggests that stronger links between U.S. and European extension and research workers could be very beneficial because the situation in the United States appears to be moving in the direction of the European experience.

The European approach to these newer issues and to the more traditional farm problems illustrates the emphasis given to the applicability of research to current problems and issues. For example, in Belgium, the Netherlands, and France there are centers that combine very applied research and extension activities. These centers develop or test new technologies in a state-owned, on-farm situation. Such testing allows the state to assume some of the risk of new cultivars, practices, and technology, and allows farmers to observe testing on a scale that may be more closely applicable to their own farm operations. In contrast to on-farm tests in the United States, the European "implementation" farms allow for improved control of testing procedures and the accumulation of considerable data such as temperatures, irrigation applied, all inputs used, and outputs produced, which would be difficult to obtain in an on-farm setting.
In contrast to this European emphasis on applied research and testing, a thought-provoking Viewpoint by Gerber (1989) made the following criticism of the U.S. extension system:

Integration of new knowledge into the whole-farm system is often overlooked in public extension today, and specific application of new knowledge is left to the process of trial and error.

Although the European facilities for applied research tend to specialize in a few commodities, or even a single one, there seems little reason why such an approach could not be adopted for whole-farm or systems analysis of such issues as sustainable agriculture and animal welfare to identify the most functional systems and gaps in our research knowledge. Under this approach, and given the strengths of the U.S. land grant university system, the development and introduction of more ecologically sound and profitable agricultural systems, for example, should proceed more rapidly because of the full involvement and cooperation of extension and research personnel.

In summary, there are many contrasts between the European agricultural advisory services and the Cooperative Extension System in the United States. Differences include the public perceptions of and support for the agricultural sector, organizational structure, mission and objectives, funding support, and research-extension linkages. Nevertheless, close contact between the United States and European extension and research organizations can yield many benefits, including the sharing of research findings, extension program information, and innovative delivery methods.

\section{Literature Cited}

Bell, R.L. and F.M. Bunney. 1985. The new challenges for Agricultural Advisory Services, 9th Working Conf. of Directors of Agr. Advisory Serv., OECD, Paris.

Funt, R.C. 1991. Comparison of grower advisory systems in Europe. HortScience 26:103-105.

Gerber, J.M. 1989. Changing roles within horticultural extension. HortScience 24:416-418.

Nitsch, U. 1989. Present trends in European agricultural advisory services. Natl. Symp. Res. in Extension, Columbus, Ohio, 16-18 May 1989. 